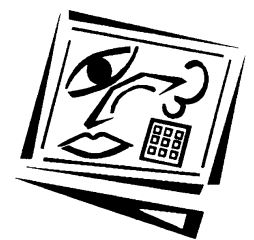

\title{
Perceptions of interactive whiteboard pedagogy in the teaching of Chinese language
}

\begin{abstract}
Hui Ling Xu and Robyn Moloney
Macquarie University

There have been many positive claims made concerning the benefits of learning through a pedagogy which makes use of an interactive whiteboard (IWB), leading to a rapid acquisition and implementation of the IWB in schools. There is more limited research, however, of the effectiveness of the IWB in language learning and, in particular, in the learning of Chinese. This case study research used both qualitative and quantitative data to collect teacher and student perceptions of the learning of Chinese through an IWB pedagogy in one secondary school in Sydney, Australia, involving students in three levels of senior secondary school. Our findings confirm previous studies which state that students endorse the use of new technology in education. In particular, our study shows that the students believed that the IWB was effective in enhancing various aspects of their Chinese language learning. The positive attitude of the teacher towards the use of new technology in teaching is also found to play an important role in the implementation and success of the use of the IWB and in turn leads to the effective teaching and learning of Chinese. This study contributes to attention within research to the application of new technology in language learning.
\end{abstract}

\section{Introduction}

The interactive whiteboard (IWB) has now been incorporated into schools and educational institutions internationally for the last ten years for the teaching of various school subjects, in particular, in teaching mathematics, literacy and science, and has generated enthusiasm from students, parents, and teachers. The use of this innovative pedagogy has attracted robust research interest (for a review, see Smith, Higgins, Wall \& Miller 2005), with many positive claims made for its educational benefits, for example, in its ability to capture students' learning interests, in increasing participation and engagement, and in developing learning skills.

There is, however, limited research into the application and success of the IWB in the teaching and learning of foreign languages. This article reports the findings of a study which investigated the perceptions of a teacher and students of the effectiveness of the IWB in facilitating Chinese language learning. An additional area of interest was the possibility, in the students' perception, of an intersection between classroom technologies and students' use of technologies outside school. This study therefore contributes to attention within research to the application of new technologies in language learning. Section 2 presents an overview of relevant literature. Section 3 is a presentation of the study's methodology and research results. In Section 4, the findings are discussed in relation to our research questions, and Section 5 offers some concluding remarks and future research directions. 


\section{Review of the literature}

An IWB is a presentation device or touch screen, the size of a conventional whiteboard, which interfaces with a computer and a projector. The screen can be touched by either a hand or with a special stylus, as well as by using the computer mouse or keyboard. Extant literature has indicated that the affordances of such a device are far greater than its parts each can achieve (see, for example, Kent, 2006; Betcher \& Lee, 2009), resulting in rapid introduction of this technology into schools in the UK, the US, Canada, and in more recent years, Australia (Thomas \& Jones, 2010). As an innovative teaching and learning tool, the IWB has generated robust research interest among practitioners and researchers in an effort to help shed light on its potential, its benefits, advantages or limitations, and impact on teaching and learning. As part of this research effort, the current study will examine IWB practice through accessing the perceptions of a teacher and students.

The IWB has been widely used in the teaching of science, mathematics and literacy subjects at the primary and secondary levels. A body of relevant research reports various perceived benefits, in light of the technology's affordances. For example, Betcher and Lee (2009) believe that as a fully integrated, multimedia enabled, large screen digital convergence facility, IWB enables the classroom to be 'agile' so that the course of a lesson can be changed at short notice to pursue unplanned-for student interests, helping to connect concepts being studied to new concepts or ideas. Kent's study (2006) also confirms the benefits of this agility of the classroom enabled by IWB. In a mathematics context, for example, Kent notes that teachers can move easily among virtual graphics calculators, spreadsheet programs, learning objects and mathematics based software applications. They can use real world examples captured by digital camera or as live data sourced in real time from the Internet.

The easy incorporation of multimedia into lessons, and access to the Internet, also support different learning styles, allowing for visual, auditory and kinaesthetic input (Tozcu, 2008) and quicken the pace of lessons (Beauchamp \& Parkinson, 2005; Betcher \& Lee 2009). The technology allows teachers and students to capture material digitally from a number of sources and then cut and paste them together to create new multimedia materials, contextually relevant to students and their learning needs. Not only does the IWB promotes co-construction of knowledge and learning materials such as this, it is also said to promote co-learning, giving students greater learning responsibilities, i.e. proactive learning, as the role of the teacher has shifted towards more as a coach, observer and facilitator (Beachamp \& Parkinson, 2005).

Other perceived benefits of the IWB reported in the literature also include increased student motivation, engagement and interactivity, thus engendering more effective learning. Interactivity is now recognised as one key to learning and sustained interest (Higgins, Beauchamp \& Miller, 2007), and is the focus of a number of studies (Levy, 2002; Cutrim Schmid, 2008; Littleton, 2010, among others). The notion of IWB interactivity may involve students' physical movement in the classroom, cooperation, collaboration and competition. The inclusion of audio and visual resources and the IWB's ability to make digital objects movable may be important in getting the students to interact with the board, with each other, and with the teacher. Increasingly, however, practitioners have also come to recognise the importance of using the IWB to promote cognitive and deeper interaction. For example, Hennessy, Deaney, Ruthven and Winterbottom (2007) highlight the fact that IWB interaction is about shared 
cognition, especially in the articulation, collective evaluation and reworking of the students' own ideas, and co-construction of new knowledge. They anticipate an 'enhanced interactive' pedagogy in which there might be less dependency on front of class teaching and increased use of pair and group work.

Research studies have also focused on the shift in pedagogy needed to exploit the advantages of the IWB. A major advantage of IWB, according to Asmawi (2007), is that the use of the IWB in teaching can be categorised into three modalities of learning: (1) visual learning through the use of text and pictures, animation and video, (2) auditory learning through pronunciation, listening to sounds or music, and (3) tactile learning through the students' physical interaction with the IWB. The extent to which these three modalities are incorporated into a lesson may determine the extent to which students are engaged in the learning process and their motivation to learn. Glover \& Miller (2001) report that several teachers in their study failed to appreciate the fact that interactivity requires a new approach to pedagogy. In a later study, Miller \& Glover (2007) concluded that a more rapid progression from a didactic to an interactive teaching approach could be made through ongoing professional development.

Of relevance to this project are studies which have identified affordances of IWB of particular application to language education. The component communication skills associated with effective language learning involve speaking, reading, writing and listening development, memory recall, metalinguistic skills involving manipulation of syntactical patterns (Pachler, Barnes \& Field, 2009; Brown, 2007) and intercultural or pragmatic skills (Scarino \& Liddicoat, 2009). Effective language education is thus considered to involve two things, the production of language in social interaction, and the opportunity for students to engage with peers in interactive critical reflection about their relationship with languages and cultures (Liddicoat, Papademetre, Scarino, \& Kohler, 2003). In light of these expectations, what are some research findings, limited as there are, on the role of IWB in relation to language teaching and learning?

In a study carried out by Gray, Hagger-Vaughan, Pilkington and Tomkins (2005), a number of areas of the effectiveness of the IWB in the teaching of languages were reported. Teachers commented that the IWB supported them in encouraging students to practise and recycle recently presented language. They reported that students were 'much more focused on the words and spellings, and even though they wrote less themselves, that this was improving their writing'. Visual effects such as colour highlighting and animation were felt to be the most important aids in drawing attention to language patterns. The study reported that the IWB, often in conjunction with the use of PowerPoint slides, offered teachers a range of easily accessible ways of drawing attention to grammatical features and patterns and that learners felt that the use of the IWB had a positive effect on memorisation skills and writing development. It also found that where language lessons were carefully planned, with well-sequenced activities ready at a touch of a button, teachers appeared to have more time to engage with students' learning. The study concludes that, though teachers initially need extra preparation time, the IWB is a support for good language teaching and in supplementing the balance of activities needed, facilitating a range of practical, hands on, kinaesthetic activities.

With regard to the teaching of Chinese using IWB, there has not been much research done so far. However, in an empirical study by Tozcu (2008:164), it has been found that the challenging teaching of a non-Roman script can be usefully supported by the 
IWB: the visual presentation appearing to shorten the acquisition period in learners. Pang $(2006,2008,2009)$, the participant teacher in this study, who has developed and promoted IWB pedagogy for learning Chinese, reports evidence that as a result of her IWB pedagogy, students' academic results improved, and that she was able to compact the syllabus, increase pace, and reach learning goals more quickly. Pang states that her pedagogy reflects the goals established by Betcher and Lee (2009), in which the authors described three phases of teacher development in their use of the IWB across the curriculum: Phase 1, doing old things in old ways; Phase 2, doing old things but in new ways; Phase 3, doing new things in new ways. Pang describes in Section 2 below her teaching characteristics which she considers to represent Phase 3 . These characteristics include the use of software which enables students to manipulate language, the facilitation of students' ability to engage in life in another context, increased levels of interactivity and student involvement, and the use of interactive voting systems (Betcher \& Lee, 2009).

Language learning in schools is, in the Australian context, an elective study choice. Student motivation and engagement are thus high priorities for teachers, both for their intrinsic value, and for their role in supporting sustained language study choices. Elearning, that is, the application of innovative technology such as the IWB certainly, has played an important role in addressing this issue. While a large number of uncontrolled variables and factors can affect student motivation, Weimer (2001) reports on the findings of a study which shows a clear link between motivation and technology. The visual aspect of the IWB has been proposed as the primary reason for active motivated engagement in the learning process (Beeland, 2002). Smith, Hardman and Higgins (2006) also found that pupil interest in learning is enhanced because of the element of visual surprise that the IWB brings to lessons. The opportunity that it gives students to present and discuss their work was also seen as improving attention and engagement in the learning process. Scarino and Liddicoat (2009) stress that we can use technology to provide opportunities for students to make language choices, to create tasks, to use games, to explore texts, to engage students in language and culture simulations, and that the use of technology makes the target language more present in students' lives. This reflects the broad question being asked (White, 2007) about students' perception of continuity or discontinuity between the classroom and their lives outside school. That is, to what extent does the rapid increase in students' use of social technologies and 'playful experimentation' with new technologies (Turkle, 1995:267) impact on new patterns of engagement and learning?

Extant literature on the application of IWB also includes comments on its limitations and disadvantages as well as suggestions and implications. In the language learning context, for example, Gray et al (2005) point out that speaking practice is found to be not well facilitated by IWB pedagogy, which seems to be in accordance with our findings in this study. They also suggest that the IWB might force students into a passive role where the ICT appears to be used for its novelty value, or when its link with the achievement of learning objectives is unclear.

Although the limited relevant studies provide evidence that student language learning, motivation and engagement may be positively affected by the use of the IWB, teachers need to be supported in their professional development in adapting their pedagogy in lesson preparation. The IWB may be considered more as a useful supplement to good pedagogy rather than as a complete pedagogy in itself for the teaching of languages. As Betcher and Lee (2009: 8) commented, "What makes the 
difference is the teacher who understands how to tap into the potential of this new technology to create engaging, interesting, interactive lessons that capture the attention and imagination of the students in pedagogically sound, creative ways."

\section{The study}

\section{Aims of the project}

A recent large-scale report on Chinese language education in Australian schools has found that various factors have affected both the retention rate and the achievement of expected proficiency in Chinese (Orton, 2008). Apart from pedagogical challenges in the classroom context such as the lack of target language-competent speakers to interact with, and external factors such as the lack of support at various levels, the intrinsic difficulty of the Chinese language, such as tones and characters, is also found to be a restriction for students of English-speaking backgrounds (Orton, 2008:5). To overcome the daunting task of learning Chinese, the report made numerous recommendations such as a greater use of modern technology to assist in oral, reading and writing competence (Orton, 2008:33). This case study is therefore timely. Its aim was to study an Australian school where one teacher is actively applying the IWB in the teaching and learning of Chinese. Specifically, this study investigates, within the following four objectives, students' and teacher's perceptions of the use of the IWB in learning Chinese:

1. To observe how the IWB is being used by the teacher in the classroom.

2. To investigate students' perceptions of the advantages and disadvantages of this technology.

3. To investigate the teacher's views on the use of the IWB.

4. To investigate if there is a continuity in the use of technology inside and outside school.

While the second and third objectives are the main concern of this study, the first objective serves as a backdrop for the researchers to understand students' perceptions and responses with regard to classroom IWB activities. Tapscott (2009) claims that if we understand the 'Net Generation', we can understand the future. Thus, we include the fourth objective in the hope that the information yielded would be useful for educational practitioners when developing technology-based pedagogical practice to meet the needs of students growing up in a digital world.

\section{Site and participants}

The case study school is an independent girls' school, encompassing both primary and secondary levels, both day and boarding school, in Sydney, Australia. The school follows the NSW Board of Studies Curriculum and Language syllabus (Board of Studies NSW, 2003), and prepares students for the NSW Higher School Certificate (HSC). The school was selected for the study due to its sustained inclusion, over at least five years, of technologies in pedagogy, and in particular its provision of IWB units in classrooms.

Student participants were the students in the Chinese classes of Years 10, 11 and 12. The total number of student participants was 18. Among the students, there was a considerable diversity in the years they had spent at the school and the amount of time 
they had studied Chinese. Students had been exposed to IWB Chinese teaching for up to 6 years. Student information from interview data indicated diversity in family, cultural and linguistic backgrounds.

The female teacher, of Hong Kong background, is between 30 and 40 years of age, and has taught at the school for eight years. The teacher was chosen due to her prominence as a proponent of the application of IWB in her Chinese teaching. She has regularly been involved, as part of professional development, in teaching both experienced teachers and pre-service teachers how to use the IWB and in promoting its benefits (Pang, 2006, 2008, 2009). The teacher began developing her IWB pedagogy in 2004, and uses a range of technology-related skills both in her school life and private life.

The two researchers are both trained language teachers in the secondary and tertiary contexts.

\section{Methodology}

This project used four data collection tools including both quantitative and qualitative methods:

- Classroom observation. This was included to capture the interaction between teacher and students and to observe the nature of the IWB activities used. For each level of Year 10, 11 and 12, three fifty-minute lessons were recorded with a total observation of nine lessons. Classroom observations were video recorded. Researchers also took detailed field notes while watching the lessons.

- Student survey (Appendix 1). The survey was administered to all three year-levels. The questionnaire consisted of 22 statements with a Likert-scale response, a ranking exercise of the importance of various aspects related the IWB and a question to find out what technologies students use outside of school.

- Focus group interview (Appendix 2). In order to capture the students' more personal metacognitive responses to their learning and more analytical reflections, 30minute focus group interviews were conducted, audio recorded, transcribed and analysed. Student participation was on a volunteer basis. The small sample size is due to the small class numbers.

- Teacher interview. Semi-structured interview questions investigated the teacher's practice and views concerning the effectiveness of the IWB, students' learning, and possible limitations of the IWB. The interview was audio recorded, transcribed and analysed.

The transcripts of interviews with the teacher and student groups were thematically and inductively coded by Content Analysis (Ryan \& Bernard, 2000). A form of methodological triangulation was achieved through the use of the different sources of data, exploring pedagogy and student learning from the different perspectives represented.

\section{Results and discussion}

\section{Classroom observation}

Classroom observation was carried out to provide the context for better understanding of our response data. Nine classroom lessons were observed and video recorded, and notes were taken. Pedagogy observed in Year 10 and 11 included the use of the IWB to 
facilitate the following activities: language games, such as the use of voting devices for such activities as expression of preferences, oral repetition of listening materials, teacher explanation of syntax, pattern practice and manipulation of syntactical elements on the board, reading aloud from text on the board, which can be recorded on the IWB and played back. Year 12 classes featured also text analysis, by annotating a text on the IWB (reading comprehension). The annotated text was then saved and emailed to all the students. Another Year 12 activity was a collaborative writing task on the IWB, which was also then saved and emailed to them. Segments of cultural information were accessed through relevant cultural websites in all classes observed. The teacher made extensive use of the capabilities of the IWB, its software, its ability to project selected teaching text materials from $\mathrm{CD}$ and its Internet capacity. In summation, the IWB is central to her teaching and is the resource focus of her classroom. The pedagogy seen in this Chinese language classroom case study matches some elements of the enhanced interactive stage, described by Miller, Averis, Door and Glover (2005), that is, the fluent integrated use of the board, awareness of its capability and facilitation of an enhanced active learning in students. The teacher appeared to be confident and experienced in the use of the board and its related technologies.

The design and progress of the lessons may be described as technology-centred, although significant student collaboration and interaction are involved in tasks. The New South Wales Quality Teaching Model (White, 2007) proposes that three dimensions are involved in quality teaching: intellectual quality of content, supported by a quality learning environment and by the perception of the significance of learning. Significance refers to making learning meaningful and important to learners, drawing connections with prior knowledge and contexts outside of the classroom and facilitating multiple ways of knowing or cultural perspectives. The IWB pedagogy observed reflected intellectual quality in its facilitation of construction of language and in depth understanding. It provided a quality learning environment, where teacher and students worked productively in a classroom focused on learning, with high expectations and positive relationships. This third aspect will become visible in student perceptions, in the analysis of student interview data below.

\section{Student survey data}

The survey was administered at the beginning of the second semester (September) 2009. The survey questionnaire consists of three parts. Part one has 22 questions which were grouped broadly in four dimensions, concerning the use of the IWB in the following contexts:

1. promotion of students' engagement and motivation (Questions 1 to 3);

2. improvement of language skills (Questions 4 to 9);

3. improvement of teaching and learning outcomes (Questions 10 to 19);

4. possibility of limitations and negative perceptions (Questions 20-22).

Each of these questions is followed by a five-point Likert scale, with the alternatives labelled from 'Strongly disagree' (1) to 'Strongly agree' (5). To avoid the halo effect, several questions were phrased negatively. The anonymous survey data was analysed with the assistance of statistical analysis software SPSS and the results are presented below in Table 1. 
Table 1: Student survey data Likert scale 1-5 response to statements $(\mathrm{N}=18)$

\begin{tabular}{|c|c|c|c|c|c|c|c|}
\hline \multirow{2}{*}{\multicolumn{2}{|c|}{ The IWB }} & \multirow{2}{*}{ Min } & \multirow{2}{*}{ Max } & \multirow{2}{*}{ Mean } & \multirow{2}{*}{$\begin{array}{l}\text { Std } \\
\text { dev }\end{array}$} & \multicolumn{2}{|c|}{ Skewness } \\
\hline & & & & & & Stat & Std error \\
\hline 1 & increases motivation & 2 & 5 & 3.94 & .725 & -.955 & .536 \\
\hline 2 & makes it more interesting & 3 & 5 & 4.39 & .608 & -.408 & .536 \\
\hline 3 & encourages participation & 4 & 5 & 4.72 & .461 & -1.085 & .536 \\
\hline 4 & helps me remember vocabulary & 2 & 5 & 3.33 & .840 & .074 & .536 \\
\hline 5 & helps good accent & 1 & 4 & 2.78 & .732 & -.629 & .536 \\
\hline 6 & improves my listening & 2 & 5 & 3.72 & .826 & -.813 & .536 \\
\hline 7 & improves fluency & 2 & 4 & 3.00 & .686 & .000 & .536 \\
\hline 8 & helps me remember characters & 2 & 5 & 3.94 & .802 & -.663 & .536 \\
\hline 9 & helps me write better & 2 & 4 & 2.89 & .676 & .132 & .536 \\
\hline 10 & increases awareness of life in China & 1 & 4 & 2.50 & .924 & -.252 & .536 \\
\hline 11 & helps me study for exams & 2 & 5 & 3.17 & .707 & .873 & .536 \\
\hline 12 & $\begin{array}{l}\text { connection to multimedia helps me retain } \\
\text { information }\end{array}$ & 3 & 5 & 3.67 & .594 & .210 & .536 \\
\hline 13 & allows me to retain more information & 4 & 5 & 4.50 & .514 & .000 & .536 \\
\hline 14 & helps me grasp ideas & 3 & 5 & 4.00 & .686 & .000 & .536 \\
\hline 15 & makes my results better & 2 & 5 & 2.89 & .758 & 1.105 & .536 \\
\hline 16 & makes learning easier & 2 & 4 & 3.61 & .608 & -1.362 & .536 \\
\hline 17 & allows extension work & 2 & 5 & 3.06 & .725 & .955 & .536 \\
\hline 18 & is best for teaching and learning languages & 3 & 5 & 4.39 & .608 & -.408 & .536 \\
\hline 19 & is not as good as a textbook & 1 & 3 & 2.39 & .778 & -.852 & .536 \\
\hline 20 & is used too much & 1 & 3 & 2.11 & .583 & .016 & .536 \\
\hline 21 & can be boring & 1 & 4 & 2.39 & 1.195 & .063 & .536 \\
\hline 22 & is not good for teaching some activities & 2 & 5 & 3.50 & .924 & -.252 & .536 \\
\hline
\end{tabular}

A comparison of the mean scores on the questions show that the first three questions, which gauge students' views on engagement of learning, encompassing motivation, interests and participation, scored relatively high, with mean scores nearing 4 and above. The second dimension, reflected in questions (4) to (9), focuses on what the IWB does best in facilitating acquisition of language skills. We were surprised to find that the results show relatively lower rating to these statements. However, a closer look at each question shows that in the eyes of the students, the most effective functions of IWB is in helping them remember characters (question 7). Given that learning characters is generally perceived as a difficult task for English speaking students, this finding certainly has positive implications for the design of teaching activities to assist students in this linguistic aspect. Slightly lower in terms of rating is in improving listening (question 6), and remembering vocabulary (question 4). But IWB does not do so well in helping oral proficiency (questions 5 and 7). This might have to do with the individual teacher's choice of IWB activities and it seems in accordance with our observation that only limited speaking practice was done in the classes observed. Also worth noting is that students gave a low rating to statement (9) which is concerned with writing skills.

Examining the scores of questions 10 to 18 shows that in terms of whether IWB facilitates teaching and learning outcomes, students' ratings are generally positive. For example, students highly endorse the use of IWB in teaching and learning foreign languages (question 18). They also believe that IWB assists the learning process by helping them retain more information and grasp ideas better (questions 13 and 14); it also makes learning easier and to some extent, helps them study for exams and allows extension work (questions 16, 11, 17 respectively). However, it appears that these 
perceived advantages did not translate directly into better study results, as indicated in the response to question 15 which scores a mean of less than 3 . While this is surprising, we believe that there are many other factors at work, not captured in this case study, to enable one to achieve high linguistic proficiency. Another surprising finding is that cross-cultural awareness was not perceived to be enhanced by the use of IWB, given that one of the great functions of IWB is its easy incorporation and access to the Internet and all the global content it can bring to viewers in a fraction of time. But as our subject sample is small, we cannot conclude that this is a general disadvantage of the IWB.

The last four questions of Table 1 are designed to find out whether students believe that there are limitations of the use of IWB in the teaching and learning of Chinese. The results show that the responses to these few questions score relatively low, suggesting that the students on the whole would prefer a more multimedia-based pedagogy than a more traditional approach.

In order to consolidate the findings of the Likert scale questions, we gave students a ranking exercise whereby they ranked the relative importance of six aspects of IWB (see Appendix 1). The results, shown in Figures 1 and 2, strongly support other sources of data which confirmed that the visual, interaction and fun aspects are very important to the students, but whether it is part of a multimedia approach, it is effective in presenting language content, or it is good to have modern technology in language teaching are relatively unimportant. What these results are telling us is that students are no longer overwhelmed by the novelty of using technology itself, in the educational context, as they grow up in this e-era, but that if there are any technologies to be used in the classroom, they would like them to be fun and interactive.



Figure 1: Visual, interaction and fun rankings $(\mathrm{N}=18)$ 


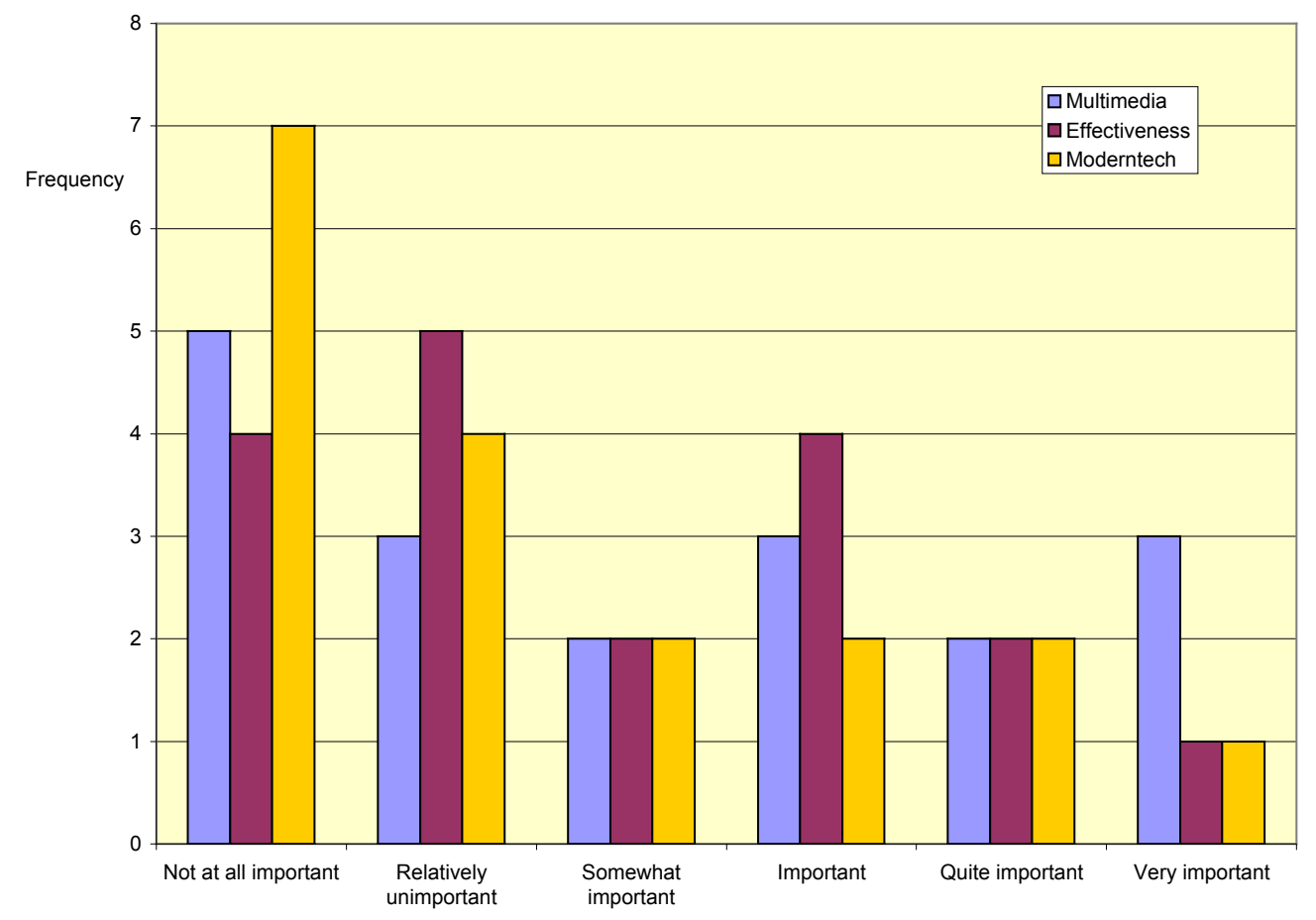

Figure 2: Multimedia, effectiveness and moderntech rankings ( $\mathrm{N}=18)$

With regard to technologies students use outside the school, Table 2 shows 'iPod', 'games' and 'YouTube' are what the students use most. Even though they also use websites, they do not use 'podcast' as much. This may be because the contents of podcast are seen by the students as irrelevant to their study or not as interesting as games or YouTube.

Table 2: Technologies students use outside school

\begin{tabular}{|l|c|c|c|c|c|c|c|}
\hline & Podcasts & $i$ Pod & Websites & YouTube & Games & Study sites & Other \\
\hline Chosen & 2 & 11 & 10 & 10 & 11 & 6 & 10 \\
\hline Not chosen & 16 & 7 & 8 & 8 & 7 & 12 & 8 \\
\hline$\%$ Chosen & $11 \%$ & $61 \%$ & $56 \%$ & $56 \%$ & $61 \%$ & $33 \%$ & $56 \%$ \\
\hline
\end{tabular}

\section{Student focus group data}

The interview questions for student focus groups were similar to the survey questions but allowed for more in depth discussion and personal reflections. A number of recurring themes emerged from the student data, as displayed in Table 3 below.

It will be noted that across the three year groups some themes were represented in common while other themes are represented differently. While the sample is small, some observations can be made, as discussed below. 
Table 3: Number of students who mentioned thematic items in focus group interviews

\begin{tabular}{|l|c|c|c|c|}
\hline & $\begin{array}{c}\text { Yr10 } \\
\mathrm{n}=7\end{array}$ & $\begin{array}{c}\text { Yr11 } \\
\mathrm{n}=8\end{array}$ & $\begin{array}{c}\text { Yr12 } \\
\mathrm{n}=3\end{array}$ & $\begin{array}{c}\text { Total } \\
\mathrm{N}=18\end{array}$ \\
\hline The IWB is fun & 6 & 4 & 0 & 10 \\
\hline The IWB gives confidence & 4 & 2 & 0 & 6 \\
\hline The IWB is interactive & 7 & 8 & 0 & 15 \\
\hline The visual aspect is helpful & 6 & 5 & 3 & 14 \\
\hline The IWB helps me remember & 6 & 3 & 1 & 10 \\
\hline The IWB creates physical movement in room & 3 & 1 & 1 & 5 \\
\hline The IWB helps character writing & 3 & 1 & 1 & 5 \\
\hline The IWB sometimes wastes time & 1 & 4 & 3 & 8 \\
\hline The IWB allows sharing of study resource & 0 & 1 & 3 & 4 \\
\hline $\begin{array}{l}\text { The IWB connects Chinese with out of school use of } \\
\text { technologies }\end{array}$ & 5 & 4 & 3 & 12 \\
\hline
\end{tabular}

Due to the similarity of questions, there is some consistency between the survey data and this interview data. However, the interview data reveals more depth and some extra aspects of student perceptions of IWB use. Four themes emerging from this data will be discussed below. The themes are:

- Interactivity, associated with engagement and motivation

- Visual presentation and recall abilities

- Connectedness of Chinese with out of school use of technologies

- Diversity in student perceptions and possible limitations

\section{Interactivity and engagement}

From Table 3 interview data, all students in Years 10 and 11 were keen to emphasise their positive perception of interactivity in class through IWB language learning activities and games. Classroom observation confirmed that students interacted frequently through competitive IWB games involving manipulation of language elements and the use of IWB voting devices.

Year 10 students stressed their enjoyment of '...games that we can play so it's like we're actually interacting, like playing' (Year 10 Student 1 ). They recognise that games create a positive learning environment: '... like everyone's screaming and like it's really fun' (Year 10 Student 2). They also recognise that games represent learning functions: 'We play games sometimes for reinforcement' (Year 11 Student 1).

Student comments suggest a confirmation of the finding by Moloney (2008) that students perceived games as a vehicle for purposeful language. Year 10 unanimously expressed enjoyment of using IWB interactive voting devices (referred to as 'cool gadgets'). Cutrim Schmid (2007) has studied the use of these voting devices in language learning and attributes their use with enhanced self-esteem in learners. Year 10 students reported they were keen to get out of their seats and participate in IWB activities.

We may observe student expression of their enjoyment of the IWB activities as a motivating factor in their Chinese study. Students drew comparisons with their other subjects, firstly in the pedagogical models they observe: '...makes the class more interactive and gets the students involved rather than the teacher standing in front of the classroom like our other subjects' (Year 11 Student 3). 
Students also identify that the IWB activities define a classroom environment for them which is less stressful than other subjects and promotes self-esteem (Cutrim Schmid, 2007).

I really like Chinese. I look forward to it, as it is fun. (Year 10 Student 6)

Because you enjoy it more and it doesn't seem like a lesson, it's more a learning experience. (Year 11 Student 2)

I can just chill out. The IWB makes it fun. (Year 11 Student 1)

....Not such a heavy feeling going to class. (Year 10 Student 4 ).

Students also aligned the interactivity of IWB activities with the facilitation of shared social benefits or personal development: 'Doing the games fosters more friendships' (Year 11 Student 2). 'The IWB is interactive and collaborative. It allows different people to come together' (Year 11 Student 2).

Year 12 students discussed different motivating factors aligned with their needs, highlighting a specific application of interactive collaboration which motivates their senior study. In preparation for required HSC skills, Year 11 and 12 frequently participate in class in collectively analysing a reading comprehension passage of Chinese displayed on the IWB. This involves collaboratively working on the passage and annotating it with vocabulary, meanings, and notes. The collaborative work is then saved and sent by email to every student to enable further study at home. All three Year 12 students commented on the value of this practice, as, unlike the incomplete notes they may have taken as individuals, they all receive a perfect and equal set of notes. They perceive this co-created resource as an equitable practice, giving them equal opportunity for success.

\section{Visual presentation and increased recall abilities}

The most salient theme in both the survey and interview data across the three year groups was the students' perception of the visual aspect of IWB learning. Students associate the visual display of characters on the IWB with the facilitation of their learning and recall of Chinese language:

What the IWB does best is reading and listening. When I see characters, I tend to remember things more if I see and listen together. (Year 11 Student 1 )

The visual helps me improve my memory and store the character. (Year 10 Student 2)

You can colour-code the different radicals so you can remember characters easier. (Year 11 Student 3)

Visual. You can see it. It's useful for characters. (Year 12 Student 1).

Students expressed some familiarity with the current theoretical notions of learning styles, for example, the Fleming VARK model (visual, auditory, reading, kinaesthetic) (Fleming, 2010). A number of students display a degree of metacognition in identifying themselves as visual learners.

Students offered perceptions of their self-identified learning styles:

I am a photographic memory kid. It is easier to see the IWB. (Year 10 Student 4) 
I am definitely a visual learner. I have to be able to see it and interact with it. (Year 10 Student 5)

In their positive perception and analysis of their IWB learning, these students appear to suggest that the use of technologies 'changes not only one's preferred forms of learning but also beliefs about learning and knowing (Turkle, 1995:132). Prensky (2001) comments that students 'think and process information fundamentally differently from their predecessors' and has identified some aspects of student capabilities which relate to their interaction with IWB pedagogy, for example, that they think learning should be fun, they like to receive information fast, prefer visual graphics and are capable of absorbing data from a number of different sources.

\section{Perception of continuity between Chinese study and out of school use of technologies}

In both the survey data and in the interview data, students reported their out of school use of technologies as part of their Chinese learning and for social purposes. Twelve out of the eighteen students reported in interviews that at home they use some form of technology for leisure or to study, as noted above in Student survey data. They receive and submit homework online in text or media files and correspond with the teacher. This is a spatial and temporal expansion of their learning opportunities.

Students commented that in the context of their engagement with the IWB learning:

It is our generation kind of thing. We are IT users. (Year 10 Student 6)

It is a social thing now that we use technology. (Year 11 Student 2)

We are used to using (technology) already, so we don't really question why we use it. (Year 10 Student 3)

Students see that there is a connection between the study of Chinese and the context of their life outside school which is integral to their perception of Significance in learning. In the student data we see several elements described in the Quality Teaching Model (White, 2007) which suggests that Significance includes accessing students' background knowledge, knowledge integration, inclusivity and connectedness.

This data suggests that it is not only the affordance of the IWB that makes it a successful pedagogy and learning tool. Important contributing factors are the students' own capacity, skills and technological confidence which they bring to it. These things work together with the IWB and the teacher, to facilitate successful learning outcomes.

\section{Diversity of perceptions and possible limitations}

It can be seen in Table 2 that there was diversity amongst the year groups in their perceptions of the use of the IWB. For example, Year 12 students are aware of the need to complete syllabus requirements to achieve good results in the NSW Board of Studies High School Certificate, a public matriculation examination.

In Table 2, it can be seen that while 'fun' was important to Year 10, it was not important to Year 12. 'Interactivity' was important to both Years 10 and 11, but had disappeared from student perceptions by Year 12. Year 11 and 12 commented that while they had enjoyed games and the voting devices in the junior years, they 
preferred now to get on with HSC focused study. A Year 12 student referred to some of the games as '...childish. They work well with the younger girls' (Year 12 Student 1). It is recognised that between Year 10 (age 15/16) and Year 12 (age 17/18) there is a significant shift in students' social emotional and cognitive development (Meece, 1997). The teacher interview data reveals that the teacher is aware of this and, in her perception, adjusts her pedagogy accordingly.

While some girls identified themselves as visual learners, a small number of students identified themselves as having different learning styles, preferring to learn through listening, reading and writing.

My learning style is different. (Year 11 Student 2)

I am a traditional learner. I like to learn by writing. (Year 12 Student 3 )

Perceptions of possible limitations of IWB pedagogy were also evident across the age range. While Year 10 were unanimous in their perception that interaction generated through the use of the IWB is the best vehicle for all sorts of learning, Year 11 and 12 expressed that some aspects of language learning could be done better without the IWB (Table 1, Question 22). The senior students suggested that they would like more time spent on the production of spontaneous speech and the production of handwritten writing passages, neither of which would involve the IWB.

In regard to the limitations of technology, it did not appear to bother Year 10 if technology failed occasionally or was unreliable. Year 12, however, expressed some impatience if classroom time were occasionally wasted owing to technical difficulties.

The culturally diverse students of the three Year groups were asked if they had engaged in intercultural language learning. This was explained as the inclusion of discussion and critical reflection in comparing Chinese language and culture with their own first language and culture (Liddicoat, Papademetre, Scarino \& Kohler, 2003). This integrated aspect of language learning is now mandated by the current Syllabus (Board of Studies NSW, 2003). It could be that the question was not well understood or the terms were unfamiliar but students did not appear to identify this as an aspect of their learning and made little response. Classroom observation also confirmed that limited intercultural reflective questions were asked or discussed. This is not a limitation of the IWB, but perhaps indicates the need to switch off the IWB occasionally for focus on reflection and intercultural enquiry.

\section{Teacher interview data}

An analysis of the transcript of the interview with the teacher provided several supporting themes. The teacher is an enthusiast for the IWB and says she 'can't do without it now'. She believes the IWB changed her approach from a focus on teaching, to a focus on what the students were learning. She believes the IWB is a particularly suitable tool for the acquisition of Chinese characters which is the skill that students find most difficult. Her perception is that since 2004 her IWB teaching has changed, with the advent of e-books (CDs), web-based materials and online dictionaries, all of which 'started to give my lesson a lot more freedom'. The IWB allows her to make her classroom digital. 'You can use resources from all over the world'. The teacher asserts that in 2005/2006 the number of students in her elective class increased threefold. It is her impression that the IWB saves her preparation time as all preparation can be done 
on a laptop. She also stressed the inclusivity of teaching with the IWB, such as with the voting tools: 'everyone can be connected to the board'.

When asked about student outcomes, she claims that the IWB has speeded up the achievement of outcomes. 'They speak better, write better. It helps them to apply language better. It certainly improves speaking and listening outcomes. For reading and writing it helps deliver the content better'.

Innovative practices include her use of Voice Thread, an online recording tool with which students can write an article, record it online and listen to themselves, as well as the use of Skype to communicate with a sister school. The teacher stresses that 'you still have to be lively and energetic, to motivate students. A successful lesson is one where students leave with huge smile on their face, when they feel they have learnt so much'. She believes the use of email technology enables her to track student work more accurately.

The teacher stresses that her program is broader than just her use of the IWB and includes excursions relating to cultural events in Sydney. She is aware of the need for differentiation between year groups and ability levels and believes the IWB pedagogy supports both gifted and weaker students. The teacher also draws a correlation between the use of the IWB and strong HSC results. The Year 12 class observed is the first class to have been exposed to IWB teaching at the school from Year 7 to Year 12.

The teacher is proficient in using a range of technologies in her personal life. She chats in class about new technologies and new products on the market, and she believes that the use of the IWB can make learning continuous with the students' use of technology throughout their lives.

\section{Concluding remarks and recommendations}

This study set out to investigate perceptions in one school context of learning Chinese through a pedagogy which makes extensive use of the IWB. Both qualitative and quantitative methodologies were used to collect the research data. However, as the study has a relatively small subject sample, it was not the purpose of the study to conduct an exhaustive and comparative examination of learning with the IWB measured against existing practices and standards. Nevertheless, our case study confirms various research findings on the application of the IWB in the educational context. In particular, in the context of teaching and learning a non-Romanised language such as Mandarin Chinese, it shows that the IWB has a role to play in three areas of effective language learning.

Firstly, in both student and teacher perceptions, it facilitates learning that is motivated and engaged, and learning that is collaborative and co-constructed, as demonstrated by students' consistent high rating on these themes (refer to Table 1 and 3). Secondly, it demonstrates that the visual advantage of the IWB facilitates recall of Chinese characters, which has always been regarded by students and practitioners alike as one of the most formidable tasks in learning Chinese. Thirdly, as an integrated learning technology, it is perceived as meaningful and continuous with students' and teachers' use of technologies in their broader lives, and has thus created a teaching and learning space beyond the four walls of the traditional classroom. What is also significant in the findings is that the teacher's technology skills and the teacher's enthusiasm and 
positive attitude in embracing new technology in teaching the Net Gen (Tapscott, 2009: xi) play a vital role in the adaptation, implementation and creation of IWB-based activities.

As a resource in language teaching however, the IWB is not without limitations. In this particular teaching context of senior secondary Chinese learning, there were areas such as in speaking and communicative skills where the use of the IWB, in some students' perceptions, was considered not to be effective in facilitating mastery and confidence. Also of interest is the finding that the IWB was of less appeal to Year 12 students than to the younger students. The older students wanted to make the most efficient use of their classroom time, aligned with development of specific examination skills needed. The older students did not perceive games or other more animated activities to be associated with serious learning in the year in which they were to sit for university entrance exams.

Pedagogical recommendations can be drawn from this study. It is clear that the fostering of positive attitudes, and the training of teachers, in educational institutions are both necessary if the IWB is to be incorporated into existing language teaching and pedagogy in this digital age. As a useful supplement to good pedagogy, rather than a complete pedagogy in itself, the scope of applications to support engaging and effective language teaching and learning is wide-ranging, diverse and continuously expanding. As with any resource, however, there is an indication that the age and different learning needs of students should be taken into consideration by teachers both in their design of IWB activities, and in the extent of the use of the IWB. The IWB creates visual opportunities for facilitating student discussion of different linguistic and cultural perspectives, highlighted in today's intercultural approach to language learning. Deeper critical reflection about language and culture needs time, and thoughtful verbal dialogue between students, to construct knowledge together. As has been noted, there are times to turn the focus back into the body of the class, and perhaps to turn the IWB off. Professional development of teacher and student skills in dialogic intercultural enquiry has yet to be further developed, in the context of IWB pedagogy.

\section{Appendix}

Appendix 1: Student survey questionnaire and Appendix 2: Student focus group interview questions are contained in the accompanying file 'xu-appendix.pdf', URL http:/ / www.ascilite.org.au/ajet/ajet27/xu-appendix.pdf

\section{References}

Asmawi, A. (2007). Interactive whiteboard: A new dimension in teaching and learning. Masalah Pendidikan Jilid, 27, 213-219.

Beeland, W. (2002). Student engagement, visual learning and technology: Can interactive whiteboards help? Annual Conference of the Association of Information Technology for Teacher Education. Trinity College, Dublin. [verified 9 Apr 2011]

http: / / citeseerx.ist.psu.edu / viewdoc / download?doi=10.1.1.135.3542\&rep=rep1\&type=pdf

Betcher, C. \& Lee, M. (2009). The interactive whiteboard revolution: Teaching with IWBs. Melbourne: ACER Press. 
Board of Studies NSW (2003). Languages K-10 Syllabus. Sydney: Board of Studies.

Brown, H. D. (2007). Teaching by principles: An interactive approach to language pedagogy, 3rd ed. Pearson Education.

Department of Education and Training (2008). Quality teaching. https: / / www.det.nsw.edu.au/proflearn/areas/qt/index.htm

Cutrim Schmid, E. (2007). Enhancing performance knowledge and self-esteem in classroom language learning: The potential of the ACTIV ote component of interactive whiteboard technology. System, 35(2), 119-133.

Cutrim Schmid, E. (2008). Using a voting system in conjunction with interactive whiteboard technology to enhance learning in the English language classroom. Computers $\mathcal{E}$ Education, 50(1), 338-356.

Fleming, N. D. \& Mills, C. (1992). Not another inventory, rather a catalyst for reflection. To Improve the Academy, 11, 137-149. [verified 9 Apr 2011] http: / / canterbury-nz.academia.edu/ ColleenMills/Papers /242118/Not_Another_Inventory_Rather_a_Catalyst_for_Reflection

Fleming, N. D. (2010). VARK - A Guide to Learning Styles. http:/ / www.varklearn.com/english/index.asp

Glover, D. \& Miller, D. (2007). Into the unknown: The professional development induction experience of secondary mathematics teachers using interactive whiteboard technology. Learning, Media \& Technology, 32(3), 319-331. [verified 9 Apr 2011] http: / / www.informaworld.com/ smpp/ section?content=a781206019\&fulltext=713240928

Gray, C., Hagger-Vaughan, L., Pilkington, R. \& Tomkins, S. (2005). The pros and cons of interactive whiteboards in relation to the key Stage 3 strategy and framework. Language Learning Journal, 32, 38-44. [verified 9 Apr 2011] http:/ / www.ittmfl.org.uk/modules/ict/2c/ paper2c1.pdf

Hennessy, S., Deaney, R., Ruthven, K. \& Winterbottom, M. (2007). Pedagogical strategies for using the interactive whiteboard to foster learning participation in school science. Learning, Media and Technology, 32(3), 283-301. [verified 9 Apr 2011]

http: / / www.informaworld.com/smpp / ftinterface $\sim \mathrm{db}=$ all $\sim$ content $=\mathrm{a} 781204804 \sim$ fulltext=71 3240930

Higgins, S., Beauchamp, G. \& Miller, D. (2007). Reviewing the literature on interactive whiteboards. Learning, Media and Technology, 32(3), 213-225. [verified 9 Apr 2011] http: / / www.informaworld.com/smpp/ftinterface $\sim \mathrm{db}=$ all $\sim$ content=a781205355 fulltext=71 3240930

Kent, P. (2006). Using interactive whiteboards to enhance mathematics teaching. Australian Primary Mathematics Classroom, 11(2), 23-26. http:/ / www.eric.ed.gov:80/ ERICWebPortal/ contentdelivery / servlet/ERICServlet?accno=EJ793925

Levy, P. (2002). Interactive whiteboards in learning and teaching in two Sheffield schools: A developmental study. Department of Information Studies, University of Sheffield. [verified 9 Apr 2011] http: / / dis.shef.ac.uk/ eirg/projects/ wboards.htm

Liddicoat, A., Papademetre, M., Scarino, A. \& Kohler, M. (2003). Report on intercultural language learning. Australian Government: Department of Education Science and Training. [verified 9 Apr 2011; $2.4 \mathrm{MB}$ ] http: / / www.curriculum.edu.au/nalsas/pdf/intercultural.pdf 
Littleton, K. (2010). Research into teaching with whole-class interactive technologies: Emergent themes. Technology, Pedagogy and Education, 19(2), 285-292.

http: / / www.informaworld.com/smpp/ section?content=a924101155\&fulltext=713240928

Meece, J. (1997). Child and adolescent development for educators. New York: McGraw-Hill.

Mercer, N., Hennessy, S. \& Warwick, P. (2010). Using interactive whiteboards to orchestrate classroom dialogue. Technology, Pedagogy and Education, 19(2) 195-209.

http: / / www.informaworld.com/ smpp/ section?content=a924106035\&fulltext=713240928

Miller, D., Averis, D., Door, V. \& Glover, D. (2005). How can the use of an interactive whiteboard enhance the nature of teaching and learning in secondary mathematics and modern foreign languages? [viewed 19 May 2010 at http:/ / www.becta.org.uk, verified 24 Apr 2011 at https:// content.ncetm.org.uk/itt/sec/KeelePGCEMaths2006/InteractiveWhiteboard\& DataProj/Research/BectaReportMiller\&co.pdf

Miller, D. \& Glover, D. (2001). Running with technology: The pedagogic impact of the large-scale introduction of interactive whiteboards in one secondary school. Technology, Pedagogy and Education, 10(3), 257-278. http:/ / dx.doi.org/10.1080/14759390100200115

Moloney, R. (2008). Young language learners and their intercultural competence: An immersion classroom case study. Saarbrucken: Verlag Doktor Mueller.

Northcote, M., Mildenhall, P., Marshall, L. \& Swan, P. (2010). Interactive whiteboards: Interactive or just whiteboards? Australasian Journal of Educational Technology, 26(4), 494-510. http: / / www.ascilite.org.au/ajet/ajet26/northcote.html

Orr, M. (2008). Learner perceptions of interactive whiteboards in EFL classrooms. CALL-EJ Online, 9(2). http:/ / www.tell.is.ritsumei.ac.jp/ callejonline/ journal/9-2/orr.html

Orton, J. (2008). Chinese language education in Australian schools. University of Melbourne. Confucius Institute. [verified 9 Apr 2011; 2.93 MB] http: / / www.asiaeducation.edu.au/ verve/_resources/chinese_language_education_in_australian_schools_file.pdf

Pachler, N., Barnes, A. \& Field, K. (2008). Learning to teach modern foreign languages in the secondary school. 3rd edition. London: Routledge.

Pang, F. (2006). Teaching languages with interactive whiteboards. Proceedings of 3rd National IWB Net Conference.

Pang, F. (2008). Teaching languages with interactive whiteboards. Proceedings of Workshop. Chinese Language Teachers Association.

Pang, F. (2009). Fourteen ways to inspire your students in a language classroom. Proceedings of Chinese Language Teachers Conference. Department of Education and Training. Sydney, NSW.

Prensky. M. (2001). Digital natives, digital immigrants. On the Horizon, 9(5), 1-6. MCB University Press. http:/ / www.marcprensky.com/writing/prensky\%20$\%$ 20digital\%20natives,\%20digital\%20immigrants\%20-\%20part1.pdf

Ryan, G. W. \& Bernard, H. R. (2000). Data management and analysis methods. In N. K. Denzin \& Y. Lincoln (Eds), Handbook of qualitative research, pp. 769-802. Thousand Oaks, CA: Sage Publications.

Scarino, A. \& Liddicoat, A. J. (2009). Teaching and learning languages: A guide. Commonwealth of Australia. http: / / www.tllg.unisa.edu.au/guide.html 
Smith, H. J., Higgins, S., Wall, K. \& Miller, J. (2005). Interactive whiteboards: Boon or bandwagon? A critical review of the literature. Journal of Computer Assisted Learning, 21, 91101.

Smith, F., Hardman, F. \& Higgins, S. (2006). The impact of interactive whiteboards on teacherpupil interaction in the National Literacy and Numeracy Strategies. British Educational Research Journal, 32(3), 443-457.

Tapscott, D. (2009). Grown up digital. New York: McGraw Hill.

Thomas, M. \& Jones, A. (2010). Editorial 26(4): Preface to the Special issue. In M. Thomas \& A. Jones (Eds), Interactive whiteboards: An Australasian perspective. Australasian Journal of Educational Technology, 26(Special issue, 4), iii-vi. http: / / www.ascilite.org.au/ajet/ajet26/editorial26-4.html

Tozcu, A. (2008). The use of interactive whiteboards in teaching non-Roman scripts. Computer Assisted Language Learning, 21(2), 143-166.

Turkle, S. (1995). Life on the screen: Identity in the age of the Internet. NY: Simon \& Schuster.

Wall, K., Higgins, S. \& Smith, H. (2005). 'The visual helps me understand the complicated things': Pupil views of teaching and learning with interactive whiteboards. British Journal of Educational Technology, 36(5), 851-867.

Weimer, M. (2001). The influence of technology such as a SMART Board interactive whiteboard on student motivation in the classroom. Smarter Kids Foundation. [verified 8 Apr 2011] http: / / downloads.smarttech.com/media/sitecore/en/pdf/research_library/k-12/the_ influence_of_technology_such_as_a_smart_board_interactive_whiteboard_on_student_moti vation_in_the_classroom.pdf

White, K. (2007). Interactive whiteboard trial, South Western Sydney Region: A report. Centre for Learning Innovation, Department of Education and Training, NSW. [verified 8 Apr 2011] http: / / www.cli.nsw.edu.au/cli/files/interactive_whiteboard_trial_easiteach.pdf

Authors: Dr Hui Ling Xu

Chinese Program, Department of International Studies, Macquarie University

Email: huiling.xu@mq.edu.au

Web: http:/ / www.asianlang.mq.edu.au/ chinese/staff/staff-huilingxu.html

Dr Robyn Moloney

Department of Education, Macquarie University

Email: robyn.moloney@mq.edu.au

Web: http: / / www.educ.mq.edu.au / contact/our_staff/dr_robyn_moloney.jsp

Please cite as: Xu, H. L. \& Moloney, R. (2011). Perceptions of interactive whiteboard pedagogy in the teaching of Chinese language. Australasian Journal of Educational Technology, 27(2), 307-325. http: / / www.ascilite.org.au / ajet/ajet27/ xu.html 